SZEMES Péter

Somogy Megyei Kaposi Mór Oktató

Kórház

ORCID: 0000-0002-3143-0084

szemespeter1979@gmail.com

\section{Ady-írások a Nyugat Figyelő rovatában}

Ady Endre alkotói tevékenysége több szempontból is sokszínű volt, ám különböző területei nem kaptak azonos hangsúlyt, minősítést az életmú értékelésében. Szinte bizonyos, hogy a Nyugat hasábjain, a Figyelő rovatban közölt írásai a legritkábban említett művei között vannak. Tanulmányomban az itt megjelent, többnyire egy-egy közéleti problémához vagy müvészeti jelenséghez kötődő írásait veszem górcső alá. 1908-tól 1918-ig számtalan müre, szerzöre hívta fel a figyelmet, hazai és világirodalmi alkotásokat egyaránt méltatva vagy éppen kritizálva. Sôt, filozófiai munkáról és képzőmüvészeti kiállításról is írt a Figyelőben.

Kulcsszavak: Ady Endre, Nyugat, Figyelő rovat

Jó írók egyik fontos ismérve lehet, hogy a mennyiség helyett inkább minőségi lapközlésre törekszenek. Nem akarnak mindennel és mindenhol megjelenni, beérik néhány, számukra fontos folyóirattal. Adynak 1908-tól haláláig, tizenkét esztendőn át ilyen törzshely volt a Nyugat, amellyel különös egymásra utaltságban létezetek (Fónod 2008), s ahol versei mellett számos prózai írása is napvilágot látott. Így a nyitószámtól folytatásokban A magyar Pimodán vagy ugyancsak az indulás folyamában a Mihályi Rozália csókja című novella. A szépirodalmi alkotások örömteli, a lap minőségét emelő bőségét pedig kisesszék, rövid recenziók, jegyzetek, egy-egy közéleti problémához vagy művészeti jelenséghez kötődő tollfutamok sora egészítette ki, melyek elsősorban a Figyelő rovatban kaptak helyet. A rovat megnevezése egyébként aligha véletlen utalás a Nyugat elődjeként emlegetett, Figyelő című lapra, tipográfiájuk is egyező volt (Schiller 2008).

S hogy ezek az írások nem kevésbé voltak fontosak a költő számára, mint az ugyanitt közölt versei, arról többek között egy, a Nyugat titkárának, Havasi Irénnek 1914-ben írt levele is tanúskodik: „Még holnap csütörtökön okvetlenül küldök még egy verset. Úgy hogy péntek hajnalban ott lesz szedhetésre készen. De még okvetlenübbül [!] kérek helyet fönntartani egy »Figyelő« számára. Fehér Dezső nagyváradi lapszerkesztő jubileumáról akarok megemlékezni, mely szombaton lesz." (Kosztolánczy-Nemeskéri 2019: 948) A rovatba írt cikkek hamarosan megkapták a „figyelő” köznevet, s a korszak jeles szerzői közül nem kevesen ajánlkoztak figyelőt írni (leveleikben hol kis- hol nagybetűvel, hol idézőjelbe téve nevezik meg a műfajt).

Ezeket, a műfajilag a napi publicisztika határát érintő írásokat az Adytól megszokott igényesség jellemzi (a recenzeált könyveket többször elolvasta, a leadott szöveget is átformálta, ha kellett), személyesség határozza meg, és természetesen erős aktualitással is bírtak. Csak betegsége súlyosbodása idején történt meg, hogy hosszabb idő után írt a megjelent kötetekről, egyébként - mint a jó újságírók általában - precíz és naprakész 
volt. Ezt példázza, hogy az 1909. október 13-án kivégzett spanyol szabadgondolkodóról, Francisco Ferrerről szóló Ferrer és a legenda című szövege már benne volt a november 1-jén kijött 21. számban. Hozzátehetjük, hogy a Nyugat kétheti megjelenése ösztönzőleg is hathatott a gyors és pontos munkára.

Ady első és utolsó írásait a Figyelő rovatban akár jelképesnek is nevezhetnénk. Nyitányként az indulás esztendejének 12-13., összevont számában $A$ föld meg a város címmel barátja és $A$ Holnap antológiában szerzőtársa, Dutka Ákos nagyváradi költő második kötetét vette védelmébe, felmentve a „füzesekből városba oltott” poétát az Ady-utánzás vádja alól. Míg zárásként az 1918. évi 10. számban a „magyar és alkotásra hivatott zsenit” és „nagyszerű pedagógust”, a festőművész Hollósy Simont siratta el. Mint látható: figyelme éppúgy kiterjedt az induló tehetségre, mint a beérkezett művészre, a költőre, próza- vagy drámaíróra éppúgy, akárcsak a testvérmúzsák, a társművészetek míveseire.

$\mathrm{S}$ a tekintete által befogott széles látómezőbe - mint fentebb jeleztük - a társadalmi problémák is belefértek, igazolva a költő szociális érzékenységét. A Ferrer-írás mellett, melyben a szocialista iskolák alapítójának - akiben az újítót üdvözölte - megölésével bekövetkezett győzelméről, legendává válásáról szólt, az 1910. évi 22. számban a tanárok nehéz helyzetének jobbításáért (mely, úgy látszik, örök téma...) emelte szavát, 1911es három Hirtelen, rövid szentenciájában pedig a nagyszámú halálozással (Sok, jó rokkant ember), kissé ironikusan az úgynevezett zsidó-kérdéssel (Ama kellemetlen probléma), illetve - mint református - az erőszakosnak ítélt katolicizmussal (Az akaratlan forradalmárok) foglalkozott. Noha a Nyugat kezdetben egyáltalán nem közölt politikai írásokat, s „a lap szerkesztői csak óvatosan követték az ő politikai és társadalmi radikalizmusát" (Fónod 2008), Ady ügyesen irodalmi papírba csomagolta ilyen jellegű állásfoglalásait, ítéleteit. Kaposvár későbbi díszpolgáráról, Apponyi Albertről például így írt $A$ Jókai emberében: „Apponyit szabad, lehet szidni, magyarázni, megérteni vagy szeretni, de nem szabad s nem lehet meg nem bámulni. Élete fölött is vitázhatunk, mondhatjuk, hogy a fórumnak csak garabonciás diákja volt, de azt senki sem mondhatja: nem volt szép ez az élet. Talán se hasznos, se teremtő élet nem volt az Apponyié, de haszonleső és cinikus sem volt egy pillanatig sem. (...) Apponyi emberileg, személyében a legszebb, leggazdagabb életet élte s annyira Jókai-hős volt, hogy különben meg se lehetne érteni magyar földön az ő gyakori s szokatlan bátorságait." (Ady 1911: 792) A világháború idején aztán Jókai más kontextusban is megjelent - 1916-os A föltámadt Jókai című írásában azon töpreng a szerző, mennyire alábecsülte a nagy mesélő víziójában a század emberének pusztításvágyát. Összecseng ezzel még 1914-ből Az új militarizmus és Az egyetlenek sor$s a$, melyekben az individuumok sorsának nehézségeit, a szocializmus után az új militarizmus tömegeinek térhódítását vázolta. Ezért is fordult különös szeretettel harcba induló titkára, fogadott fia, Steinfeld Nándor felé (Hösök a költető-gépben), bátorította szintén katonának vitt „poéta-gyermekét”, aki levelében a „régi és finom idők” elmúlását panaszolta (A Bepanaszolt élet).

Aggasztotta a szülőföld, Erdély sorsa is. Már az 1914-es Háború és háborúban felmerül a román nemzetiségi kérdés rendezése, a következő évbeli 16. számban pedig bizakodva így írt Az oláh mumus című tollfutamban: „Az oláh mumus elszenvedhető, lebírható s Romániának nem kívánhatnék rosszabbat Erdélynél. Csak Kolozsvárra, Brassóra, Marosvásárhelyre s még néhány városra intek. Belepusztul az oláh, ha ilyen kultúrás helyeken el tudna helyezkedni. Szerencsére nem tud, mert Erdélyt akarjuk, tartjuk s meg is fogjuk őrizni. Az oláh mumus nem mumus s eszembe jut egy román fiskális, aki azt mondta: Isten ments, hogy Budapest helyett Bukarestbe kelljen mennem főtárgyalásra." (Ady 1915: 926) Ugyanebben a számban erre még rátett egy lapáttal a marosvásárhelyi kultúrpalota és az építő Bernády polgármester dicsérete ( $A$ Magyarság háza): „Egy fon- 
tos erdélyi város egy különösen nagyszerű ember jóvoltából kultúr-palotát csinált, különöset és nagyszerüt.

- Ez lesz, ha a Sors úgy akarja, a magyar menedék, dús és takaró. Itt fogjuk őrizni magunkat mi, magyarok, akik egymás ellen annyit vétettünk. Ide fogunk verssel, zenével, beszéddel összevonulni, ha baj lesz. S minden, képességes szeretetemmel néztem föl reá, ez úrra, mert hogy nagyon és dacos magyar vagyok s ő az én rokonom.” (Ady 1915: 926) Elég ezt a néhány sort idézni azoknak, akik szerint Ady nem volt a hazáját szerető, igaz magyar ember. S e passzusokat csak erősíti négy évvel korábbról, 1911-ből a Két meggyőződésű emberek zárlata, ahol kis csavarral, de a következőket olvashatjuk: „Büszkén s bátran vallom magamat a két meggyőződésű emberek közé e szerencsétlen országban, ahol meggyőződéstelen ember nincs, egy meggyőződésű csak a nagyon kevés számú bolondházban s a legtöbb ember ezer meggyőződésű politikai és társadalmi dolgok körül, s ahol a két meggyőződés: magyarság, emberség és tisztesség." (Ady 1911: 248)

Az irodalom terrénumára térve: Ady költői nagyságához hozzátartozik, hogy az új nyelv és új verselés mellett - melyekről Ignotus írt Halhatatlan Ady című szép, búcsúzó szövegében - poézise természetszerűen áramlott bele a kortárs világirodalom hatalmas folyamába. Mindehhez kellett a közvetlenség, a franciás műveltség, az európai gondolkodás. A Nyugat különösen párizsi tartózkodásaiból profitált sokat, hiszen az olvasók rögtön a megjelenés után értesültek tőle az új könyvekről (nem kellett évekig várni a magyar fordítások szemlézésére), az éppen zajló színházi bemutatókról. A Figyelő rovatba már 1909-ben írt Anatole France „mese-ölő új meséinek” kötetéről, a Kékszakáll hét feleségéről, mely itthon Csetényi Erzsi fordításában csak 1917-ben látott napvilágot, 1910-ben André Gide A mennyország kapuja című könyvéről, amit 1944-ben adtak ki Gyergyai Albert átültetésében, majd 1914-ben France utolsó nagyregényéről, Az angyalok lázadásáról, amelyet a későbbi miniszter és népbiztos, Kunfi Zsigmond magyarított Pártütő angyalok címmel, 1916-ban. De hírt adott a kalandos életű és „finom, ravasz, szomorú tollú" Pierre Loti és a svájci francia Binet-Valmer újabb műveiről is, akárcsak Porto-Riche, Bataille és Bernstein színházi bukásáról (Három arisztokrata bukás), Rostand Kakasának gyenge előadásáról. Az utóbbiról szóló Strófák a Chanteclerről felütéséből az is nyilvánvalóvá válik, hogy milyen szigorú főszerkesztő volt Ignotus és hogy hiába volt törzsszerző, még Adynak sem lehetett mindent a folyóiratnál. Mint írta: „A Nyugat kemény lap s ez az oka, hogy én most második kritikámat írom a Rostand darabjáról: az elsőt ugyanis nem adták ki." (Ady 1910: 563)

Párizsból válaszolt a Figyelő rovatban azoknak, így elsősorban az öreg Eötvös Károlynak, akik sokallták a Budapest irodalmi díjával neki ítélt 2000 koronát (Sokallják az éhbért), és - a szónál beszédesebb a tett - rá jellemző módon, innen is segíteni próbálta a magyar irodalom ügyét, mikor felhívta a figyelmet a Franciaországban sikert aratott kiadványokra: a milliókhoz eljuttatható hírlap-küllemű regényekre (Irodalom hírlapformában) vagy Paul Reboux és Charles Muller nagy írókat parodizáló művére (À la manière de...). Hogy értő fülekre talált, mutatja Karinthy Frigyes két évvel későbbi, Így írtok ti című pastiche-gyüjteményének megjelenése. Nem véletlen tehát a Nagy Háború idején sem Frankhon utáni vágyódása - az 1915-ös, Szép Ernőnek küldött Kis párizsi emlékezés közös élményt idéz, a megismétlést, folytatást kívánva, az 1917-es Charles Baudelaire él pedig nizzai szonettfordítási kísérleteit eleveníti fel. Bizonyára nem tudott a kint élő magyarok internálásáról, amiről később Kuncz Aladár írt a Fekete kolostorban, és természetesen azt sem sejthette - bár némelyek szerint a költők a jövőbe látnak -, hogy halála után egy esztendővel ott írják alá az országcsonkító, szülőföldjét a románok kezére játszó békét. Meg kell említenünk, hogy kiválóan ismerte az osztrák és német irodalmat is: 1913-ban szemlézte Heinrich Nowak bécsi expresszionista költő Die tragische 
Gebärde című első kötetét, s ugyanebben az évben örömét fejezte ki amiatt, hogy az általa nagyra tartott Karl Kraus és Thomas Mann egyazon este olvasnak fel Budapesten.

A Figyelő rovatban közölt Ady-írások legnagyobb része természetesen a kortárs magyar irodalommal, annak jelenségeivel foglalkozik. Dutka Ákosé mellett bemutatta a debreceni poeta doctus, Oláh Gábor verseskötetét ( $A z$ élet lobogója alatt), Halasy Imre gyenge „szatirikus hősi legendáját” (A szörnyűséges harc), a Napszállat felé című pályazáró könyvet, melynek szerzője, a megvakult Rudnyánszky Gyula szerinte „különb volt az összes korabeli Arany- és Petőfi-epigonoknál, kik hírre, polcra vergődtek, s több talán még Komjáthynál, Reviczkynél is" (Ady 1913: 140). Ajánlotta a szeretett és becsült Szép Ernő Sok minden kötetét, örült Jékey Aladár kolozsvári költő felfedezésének (Egy ifjú költó), felhívta a figyelmet Halmágyi Samu dicsőszentmártoni tanár verseire (Hadak útján) és egy különlegességre, Lepedát Milivoj magyarországi szerb katonatiszt Bánatprocesszió című könyvére is. Ha hozzátesszük, hogy ez utóbbi Nagyváradon jelent meg, még nyilvánvalóbbá válik, hogy tekintélyét, szavának súlyát kihasználva mennyire próbálta segíteni az irodalmi érvényesülésben az arra érdemesnek tartott földijeit, mennyire propagálta az Erdélyben kiadott értékes köteteket.

S a fiatalokra, a pályakezdőkre sem sajnálta az időt és a fáradságot, akiknek egy-egy elismerő szava bizonyára minden babérnál többet jelentett. Az 1912-es Számadás csöndes könyvekről két költőt említ: Zsögön Zoltánt és Fleyner Jánost, a következő évi Fiatal költők versei Tóth Árpád helyett ifjabb Bókay János és Szegő Ferenc lírai munkáit vizsgálja, az Egy ifjú író Szász Menyhért számára kért érdeklődést és szeretetet, a Hajh, mennyi költő - 1914-ből - a bő termésből néhányat emel ki: Farkas Antal, Kacskovich Tibor Béla, Ligeti Ernő, Lovag Ádám, Balázsi Podluzsányi Zsigmond és Gutman Endre költeményeit. Nem Ady hibája, hogy ezek a nevek ma pusztán irodalomtörténeti érdekességűek.

Ezekkel ellentétben komoly érték $A$ forradalmár Petőfi című írás, melyben az általa szerkesztett versgyűjtemény szervező elvét, szándékait magyarázza, a saját vegykonyhájába bepillantást engedő nyugatos temesvári előadás (Félelem és Írás) vagy a régi magyar nyelvet visszaáhító két kisesszé: a Van-e magyar nyelv? és a Szavak a patvarban. Érdemesebb lett volna a rovatban a perc-alkotókra szántak helyett több ilyen vallomásos szöveget közölni, bár bizonyára azok is tudatosan, szerkesztői szándék szerint kerültek be.

Más a helyzet a prózai teljesítményekkel, ahol Ady a jelentősebb, beérkezettebb szerzőkre figyelt. Már az 1908-as folyam 24. számában írt a Budapesti Napló korábbi főszerkesztője, a később „fogadott apjának” nevezett Kabos Ede új regényéről ( $A$ jövő fészke), 1910-ben pedig Mária látogatói című novelláskötetéről. Két évvel később Gárdonyit követte meg ifjonti lebecsüléséért - többek közt a következő szavakkal: „Boldog vagyok, hogy a Nyugatban s éppen a Nyugatban írhattam meg ezt Gárdonyiról, a Nyugatban, ahol nemcsak »lapunk íróit« lehet meglátnunk s ahol nagy öröm minden, ami szép, bárhonnan, bárkitől, bármikor s bárhogyan késve-keletiesen jön. Gárdonyi megnyergelte, megszelídítette, megfinomította a magyar anekdotát s ma Ő itt van és ír előttünk olyanként, akinek be kell vallanunk a már nagyon-elmúlt kétségeinket is.” (Ady 1912: 970) Mindez válasz is talán a korábbi, méltó íróutódot hiányoló, Ki lesz Mikszáth? címben foglalt kérdésére. 1913-ban Krúdy $A$ vörös postakocsiját dicsérte, mint az író „tegnapi ifjúságának boszorkányos muzsikájú dalát”, míg a karácsonyi könyvtermésből a Palotai álmokat, Heltai Jenőtől valószínűleg a Jaguárt, illetve Szép Ernő (Az egyszeri királyfi) és Lesznai Anna (A kis kék pillangó utazása) meséit emelte ki. Az ezeket szemléző Könyvek és jóslások már 1914-ben jelent meg, mikor a 3. számban a száz magyar író száz novelláját (köztük az övét) közreadó Az Érdekes Újság Dekameronja című kiadványt is bemutatta. A köl- 
tőként becsült Oláh Gábor Szegény magyarok című regényét ugyanakkor sajnálni valóan gyengének minősítette, Kisbán (Bánffy) Miklóst „a legszebb értelmű és úriságú amatőrírónak" nevezte. Tisztelettel emlékezett meg az 1917-ben elhunyt Tömörkény Istvánról, a szegedi magyar rajzának mesteréről, Mikszáthtal vetve össze őt (a kaszavásárló paraszt esetének idézése olvasói leveleket is eredményezett), míg a „legnagyobb palóc” Kosztolán című novellája az áruló csehek kapcsán jutott eszébe. A 16. számban Barta Lajos a Nyugat kiadásában megjelent, $A z$ élet arca elbeszéléskötetéről írt, megemlítve, hogy régóta figyeli a szerző útját, aki Móricz és Kaffka Margit óta a legtöbb örömet szerezte neki. Szokása szerint a műtől a mindennapi élet jelenségei felé is lépett, mégpedig az úgynevezett zsidó-kérdés útjára. A hol antiszemitának (Pritz 2016), hol zsidóbérencnek (Zöldi 2019) mondott Ady így írt Barta kapcsán: „A Huszadik Század-ban a magyarországi zsidó-kérdéshez kellett volna szólnom, de szándékom egy csonka s önmagamnak őrzött cikkecskébe halt. Gondolom, hogy a magyarországi zsidó-kérdésben szándéktalanul a legráhibázóbb, legérdekesebb válasz a Barta Lajos könyve.

Barta Lajos egy-két novellájában olyan zsidókat mutat meg, akik már végzetesen $\mathrm{s}$ örökre magyarok. Barta maga pedig úgy néz és úgy lát zsidót, parasztot, várost, vidéket, kishivatalnokot, vén leányságot, dús nőiséget, sok mindent, ahogyan még eddig nálunk alig láttak. És ez megint azt mondja, hogy a zsidóság egy része már olyan gyökeres magyar, mint én, te vagy bárki, akinek »a nagy világon e kívül« stb, stb. Új lendületű magyarság a Bartáé, új szemű is, de olyan átmagyarzott magyar: rá lehetne bízni a legködösebb magyar elő-időkből kiálmodni világosra a magyar életet." (Ady 1917: 321)

A költőkhöz hasonlóan figyelt a fiatal és pályakezdő prózaírókra is. Az 1912-es Számadás csöndes könyvekről Vidovich Ernő és Szudy Elemér nevét tette ismertebbé, 1914ben a később a nagyváradi Ady Endre Emlékmúzeum igazgatójává lett Tabéry Géza novelláskötetét (A clematisos udvar) mutatta be, 1916-ban Tersánszky Józsi Jenő első, háborús regényét, a Viszontlátásra drágá...-t dicsérte meg, az 1917-es folyamban pedig Mariay Ödön Aranyszájú Zongh című könyvét ajánlotta. A Barta-íráshoz hasonlóan életet és művet kapcsolt össze, mikor Thaly Kálmán kuruc korhoz térését, mint regénytémát javasolta és egyik utolsó, Daudet és Kiss című szövegében is, melyben plágium vádját vetette Kiss Menyhért író szemére, és hogy lopásával a hazáját elhagyni kényszerült székely nép fájdalmát csúfolta meg. Beszédes záró szentenciája szerint: „Éljen a kicsi ember is, ha nem - tolvaj." (Ady 1918: 359)

Noha Ady több helyütt is hangsúlyozta, hogy nem rajong a színházért, a Figyelő rovatban mégis olvashatunk néhány drámáról, színházról szóló írást is. Balázs Béla $A z$ utolsó nap című négy felvonásos drámájának kiadását „sok hibájú és szépségű könyvnek" nevezte, ellentétben Molnár Ferenc műveivel (1910-ben feltehetően a közelmúltban megjelent Liliom miatt volt az elismerés), akinek „egy nyolcvanad része is nyugtalanítóan ragyogó, hatalmas talentum" (Molnár Ferenc színpada). A kiismerni vélt G. B. Shaw Magyar Színházbeli bemutatójához, Az orvos dilemmája előadásához képest inkább Nagy Endre kabaréját dicsérte, mely szerinte „fölér egy ál-parlamenttel”. A párizsi bemutatók mellett - melyekről már szóltunk - pedig egy itáliait is megemlített: a „Herczeg Ferencbe plántált késő és rossz Mascagni”, Pucciniét (La Fanciulla del West).

A társművészetek közül két írás erejéig a képzőművészet is helyet kapott: az orvos Petz Aladár nővére, Petz Margit, a „vonal-poézis fanatikus költője” kiállításának méltatása és az említett búcsúzó szöveg a Técsőn iskolát teremtő Hollósy Simontól. Illetve Ady három, nem művészeti jellegű kiadványt is bemutatott: Madai Gyula gimnáziumi tanár $A$ költői nyelv és Csokonai című dolgozatát, a somogyi születésű Kozári Gyula honvédségi plébános Pascalról szóló filozófiai tanulmánykötetét és Ignotus Egy év történelem című háborús könyvét, melyet természetesen az egekig magasztalt. 
Végül szólnunk kell a Figyelő rovatban szereplő két évfordulós méltatásról is: 1913ból a hetven esztendős „öreg dalnok”, Kiss József köszöntéséről és a Nagyváradi Naplót főszerkesztő Fehér Dezső 25 éves újságírói jubileumának ünnepléséről 1914-ben. Hozzátehetjük, hogy az 1909. 10-11. számot (a Versek kötet megjelenésének tizedik évfordulóján) meg Adynak szentelte a Nyugat, mint ahogy - megköszönve az induló folyóiratnak kölcsönzött tekintélyt, szerkesztői munkáját, a lapnak adott, irodalmunk kincsesházát gazdagító verseit és prózáit, s talán a Figyelő rovat több mint hetven szövegét is száz esztendővel ezelőtt, halálakor ugyancsak összevont számmal búcsúzott tőle. Ebből, fejet hajtva az életmű, a költő emléke előtt és száztíz év távolából megköszönve azt, amit Somogynak, Kaposvárnak adott, és aminek szellemiségét ma is őrzi a róla elnevezett utcában álló szoborkompozíció, Rippl-Rónai József mennyországba írt levelét idézzük:

„Édes Bandikám!

Úgy szeretnék én is írni tudni, mert érzem, hogy akkor én írnám a legszebbet, hogy az én kedves, legjobb barátom, Bandi, megtudja odafenn, hogy még jobban szeretem, mint ahogy mutattam idelenn.

Soha imponálóbb, mélyebb, mokányabb szívű és lelkű embert Nálad nem ismertem. Soha őszintébbnek, igazabbnak hozzám senkit nem éreztem. Amit mondott a nagy vastagnyelvű szád, azt bizonyította álmos, nagy, fekete szemed még inkább. Tisztelettel kellett Rád tekintenem. Tisztelettel kellett minden szavamat Hozzád intéznem. Éreztem mindig, hogy ritkán szabad tréfálnom úgy, ahogy másokkal szoktam tenni. Egymáshoz való tiszteletünknél csak lelki vonzódásunk, szeretetünk lehetett nagyobb méretü - végtelenebb.

Veled vagyok édes Bandim, él bennem minden szavad, verseid pedig egész valómat betöltik. Ki hitte volna, hogy Te, nagy férfi, erős ember, halhatatlan, ily gyorsan parirozni fogsz a sovány halálnak. Szervusz drága Bandim! Nézz le olykor és láss meg bennünket! Jóskád" (Rippl-Rónai 1919: 273)

\section{Irodalom}

Ady Endre (1917): Barta Lajos könyve. Nyugat 10(16) 321.

Ady Endre (1918): Daudet és Kiss. Nyugat 11(4) 359.

Ady Endre (1911): A Jókai embere. Nyugat 4(8), 792.

Ady Endre (1911): Két meggyőződésű emberek. Nyugat 4(15), 248.

Ady Endre (1918): Az oláh mumus. Nyugat 8(16), 926.

Ady Endre (1913): Rudnyánszky Gyula könyve. Nyugat 6(2), 140.

Ady Endre (1910): Strófák a Chanteclerről. Nyugat 3(8), 563.

Ady Endre (1912): Az új Gárdonyi. Nyugat 5(24) 970.

Fónod Zoltán (2008): Ady Endre és a Nyugat. Irodalmi Szemle 51(2), 8-14.

Pritz Pál (2016): Magyar sors, magyar „fátum” Ady Endre és Jászi Oszkár élete tükrében. Kommentár 11(3), 85-97.

Kosztolánczy Tibor - Nemeskéri Erika (sajtó alá rendezte) (2019): Tessék színt vallani : Osváth Ernő szerkesztői levelezése II. Bp.: Gondolat-OSZK

Rippl-Rónai József (1919): Levél a mennyországba - Ady Endrének. Nyugat 12(4-5) 273. Schiller Erzsébet (2008): A Nyugat első száma. Holmi 20(1), 21-37.

Zöldi László (2019): Ady, a kétarcú? Kultúrszalon [online] cop. 2019. 01. 27. [2020. 02. 13.] <URL: http://www.kulturszalon.hu/?q=ady-ketarcu 


\section{SUMMARY}

\section{Ady writings in Figyelő section of Nyugat}

Endre Ady's creative activity was diverse from several points of view, but its different fields were not given the same importance or evaluated in the same way in his lifetime achievement. It is almost certain that his writings published in Figyelö (Hungarian observer) section of Nyugat („The West”) journal are among the ones which are mentioned the least. In my essay I would like to take a closer look at his writings relating to either a problem of public life or an artistic phenomenon published here. He drew attention to several works of art, authors from 1908 to 1918 praising or critcizing national and international works of art as well. What is more, he also wrote about philosphical works and fine art exhibitions in Figyelö.

Keywords: Endre Ady, Nyugat, section Figyelő 